\title{
Разломные зоны и поля напряжений в осадках центрального Байкала: тектонофизическая интерпретация гидроакустических и геофизических данных
}

Семинский К. Ж., Черемных А. С., Хлыстов О. М., Ахманов Г. Г.

\begin{abstract}
Аннотация
В результате комплексного анализа сейсмических, сейсмо- и гидроакустических материалов составлена схема разрывов, нарушающих осадки центральной части Средней котловины оз. Байкал. На основе ее тектонофизического анализа впервые показано, что разломная структура осадочной толщи является зонно-блоковой, т.е. представляет сеть зон повышенной плотности разрывов, которые ограничивают слабо нарушенные блоки. В строении крупных разломных зон северо-восточного простирания (Ольхонский, Береговой, Гидратный, Святоносский) главную роль играют магистральные сместители или их сегменты, оперяемые вторичными нарушениями. Поперечные северо-западные структуры выражены в чехле осадков широкими зонами сгущения сравнительно мелких разрывов, т.е. представляют ранние стадии развития разломов фундамента, разделяющих впадину в продольном направлении на крупные фрагменты. Зонно-блоковая структура осадочной толщи формировалась в поле напряжений сдвига, а затем в поле растяжения, которые соответствуют известным стадиям развития Байкальского рифта - ранне- и позднеорогенной. На современном этапе тектогенеза выделенная сеть разломных зон контролирует газовую (газогидратную) и сейсмическую активность недр. Гидратоносные грязевые вулканы и сипы приурочены к крупным разрывам, а эпицентры землетрясений тяготеют к разломным зонам, образуя скопления в узлах сочленения крупных северо-восточных сбросов с зонами растяжения северо-западной ориентировки и субширотными левосторонними сдвигами.
\end{abstract}

\section{Ключевые слова:}

разрывы в осадках оз. Байкал, разломные зоны, блоки, газовые гидраты, поле напряжений, сейсморазрезы 
3 Разломные зоны и поля напряжений в осадках центрального Байкала: 4 тектонофизическая интерпретация гидроакустических и геофизических данных 5

Аннотация. В результате комплексного анализа сейсмических, сейсмо- и гидроакустических 14материалов составлена схема разрывов, нарушающих осадки центральной части Средней котловины оз. 15Байкал. На основе ее тектонофизического анализа впервые показано, что разломная структура осадочной 16толщи является зонно-блоковой, т.е. представляет сеть зон повышенной плотности разрывов, которые 17ограничивают слабо нарушенные блоки. В строении крупных разломных зон северо-восточного 18простирания (Ольхонский, Береговой, Гидратный, Святоносский) главную роль играют магистральные 19 сместители или их сегменты, оперяемые вторичными нарушениями. Поперечные северо-западные 20структуры выражены в чехле осадков широкими зонами сгущения сравнительно мелких разрывов, т.е. 21представляют ранние стадии развития разломов фундамента, разделяющих впадину в продольном 22направлении на крупные фрагменты. Зонно-блоковая структура осадочной толщи формировалась в поле 23напряжений сдвига, а затем в поле растяжения, которые соответствуют известным стадиям развития 24Байкальского рифта - ранне- и позднеорогенной. На современном этапе тектогенеза выделенная сеть 25 разломных зон контролирует газовую (газогидратную) и сейсмическую активность недр. Гидратоносные 26грязевые вулканы и сипы приурочены к крупным разрывам, а эпицентры землетрясений тяготеют к 27разломным зонам, образуя скопления в узлах сочленения крупных северо-восточных сбросов с зонами 28растяжения северо-западной ориентировки и субширотными левосторонними сдвигами.

29 Ключевые слова: разрывы в осадках оз. Байкал, разломные зоны, блоки, газовые гидраты, поле 30напряжений, сейсморазрезы.

31

32 Геодинамические модели развития Байкальского рифта (рис. 1, А) в существенной з3степени базируются на закономерностях геологического строения толщи осадков в 34пределах озерной котловины. Кроме их литологии и особенностей напластования, особое 35значение в исследованиях современной геодинамики рифта имеет характер 36дислоцированности отложений и, в частности, разрывная структура. Как следует из 37многочисленных публикаций [Шерман, Днепровский, 1989; Леви и др., 1995; 1997; 38Delvaux et al., 1997; Levi et al., 1997; Moore et al., 1997; Scholz et al., 1998; Mats et al., 2000; 39Мац и др., 2001; Ceramicola et al., 2001; Логачев, 2003; Кузьмин и др., 2004; Petit, 40Deverchere, 2006; Семинский, Черемных, 2011; Семинский и др., 2013; Лунина, 2016; 41Solovyeva et al., 2020; и др.], она наиболее информативна для понимания стиля и этапов 42деструкции земной коры Байкальского рифта, поскольку дает возможность установить 43реализующиеся механизмы растяжения, реконструировать наиболее молодые 44динамические обстановки, верифицировать возрастные границы стресс-тензоров, 45восстановленных в кристаллических массивах суши. Кроме геодинамического аспекта, 46картирование разрывной структуры байкальских осадков имеет принципиальное значение 47для выявления закономерностей глубинной дегазации и геотермических аномалий. Это 48обусловлено тем, что проявления грязевого вулканизма и связанных с ними скоплений 49газогидратов контролируются зонами тектонических нарушений дна, 50характеризующимися высокой теплопроводностью [Дучков и др., 1999; De Batist et al., 
512002; Van Rensbergen et al., 2002; Klerkx et al., 2006; Cuylaerts et al., 2012; Гольмшток, 2014; 52Хлыстов и др., 2017; Khlystov et al., 2019; 2021].

53 Основой для выделения разломов в осадках озера являются, главным образом, две 54группы данных. Во-первых, это построенная по материалам многолучевой эхолокации дна 55цифровая модель (ЦМР) рельефа, спрямленные элементы которого в тектонически 56активных регионах считаются косвенным признаком наличия разрывного нарушения, а, 57во-вторых, - данные сейсмического и непрерывного сейсмоакустического 58профилирования (НСП), реализованного на Байкале в различных модификациях [Klitgord 59et al., 1993; Cuylaerts et al., 2012, Solovyeva et al., 2020], позволяющих получать разрезы 60осадочной толщи и по смещению маркирующих горизонтов выделять разрывы с высокой 61степенью достоверности. Авторы схем разломов, существующих в настоящее время для 62байкальского дна в целом или для отдельных участков [Леви и др., 1997; Moore et al., 1997; 63Scholz, Hutchinson; 2000; Логачев, 2003; Татьков, 2009; Лунина, 2016; Solovyeva et al., 642020], использовали одну из групп данных или их сочетание.

65 Комплексирование информации повышает достоверность выделения разломов, 66поскольку в этом случае площадные батиметрические материалы верифицируются 67наличием разрыва в разрезе осадочной толщи, причем качество картирования зависит от 68степени детальности геофизической съемки. Сравнительно недавно открылась 69возможность на новом уровне исследовать разломную структуру значительного по 70площади участка Средней котловины оз. Байкал (рис. 1, А), который после сейсмических 71исследований в 1992 г. и 2002 г., а также съемки дна многолучевым эхолотом в 2009 г. 72[Cuylaerts et al., 2012] был покрыт достаточно детальной сетью НСП в рамках 73шестилетних работ по проекту Class@Baikal [Ахманов, 2018; Solovyeva et al., 2020] (рис. 741, Б). Таким образом, целью настоящего исследования было выявить на основе 75комплексного анализа рельефа дна и сейсмических разрезов разломные структуры в 76центральной части Средней котловины оз. Байкал и на базе тектонофизического подхода 77установить их кинематику, главные этапы формирования и стиль деструкции осадочной 78толщи.

79

80

\section{Территория и методы исследований}

81

82 Площадь исследований представляет участок дна Средней (или Центральной) 83котловины оз. Байкал, границы которого показаны на рис. 1, А. Это часть собственно 84Байкальского сегмента одноименной рифтовой зоны, который в современную эпоху 85развивается в режиме растяжения литосферы в отличие от северо-восточного и юго86западного флангов, где присутствует сдвиговая компонента смещений [Шерман, 87Днепровский, 1989; Семинский, 2009; Саньков, Добрынина, 2015].

88 Вследствие растяжения в пределах Байкальского рифта накопилась 89многокилометровая толща осадков и располагается самое глубокое в мире озеро, причем 90наибольшие отметки дна характерны именно для Средней котловины. Несмотря на то, что 91максимальная глубина озера имеет место вне участка исследований, область отметок, 92превышающих 1500м, распространяется и в его пределы (рис. 1, Б). Она располагается в 9зсеверо-восточной части, от которой при продвижении вдоль оси на юго-запад уровень дна 94постепенно повышается до глубин 1100 м, переходя за границами участка в 95возвышенность Кукуйской гривы, сформированной за счет твердого стока р. Селенга 96[Хлыстов и др., 2016]. Эта глубокая приосевая часть рифтовой долины сменяется по 
97направлению к берегам соизмеримыми с ней по площади, менее глубокими участками дна. 98Северо-западный из них имеет характер ступени, в пределах которой глубины варьируют 99слабо, тогда как юго-восточный представляет наклоненную, изрезанную поперечными 100подводными долинами часть дна, переходящего сравнительно постепенно в береговой 101уступ.

102 Описанная морфология поперечного батиметрического профиля, как и строение 103осадочной толщи в целом, определяются разломной структурой Средней котловины (рис. 1041, А). Ограничивающие ее крупные рифтообразующие разрывы северо-восточного 105простирания на позднекайнозойском этапе развития являются сбросами. К ним относятся 106Ольхонский и Береговой разломы, представляющие тектонические границы участка 107исследований и формирующие здесь береговую линию. Северо-западной и юго-восточной 108границами глубоководной приосевой зоны, судя по опубликованным схемам [Леви и др., 1091997; Татьков, 2009; Лунина, 2016; Solovyeva et al., 2020], также являются разломы, 110отчетливо выраженные уступами в рельефе дна [Кузьмин и др., 2004]. Характерно, что к 111уступу первой из тектонических границ приурочена серия сипов и грязевых вулканов, 112один из которых - «Новосибирск» - отчетливо выражен на сейсмическом разрезе I-I' 113широкой зоной дезинтеграции осадков (рис. В-Г) [Cuylaerts et al., 2012]. Юго-восточная 114граница отделяет изрезанную поперечными подводными долинами прибрежную часть от 115заполненной осадками приосевой зоны (рис. 1, Б).

116 В целом отложения дна, судя по поперечному разрезу (рис. 2, Г), построенному с 117использованием отдельных отрезков сейсмических профилей (рис. 1, Б), залегают 118субгоризонтально. Однако с приближением к отмеченным выше разломным границам, они 119изгибаются вплоть до разрыва со смещением отдельных слоев и, наконец, всей толщи в 120целом. В ее строении участвуют 3 главных осадочных комплекса [Хатчинсон и др., 1993; 121Казьмин и др., 1995; Moore et al., 1997; Мац и др., 2001; Ceramicola et al., 2001; Мац, 2012; 1222015], два из которых, как минимум, сформировались в течение последних 30 млн лет и 123относятся подавляющим большинством исследователей к собственно рифтовому периоду 124развития региона. Первый соответствует раннеорогенному, а второй - позднеорогенному 125этапам (стадиям - по [Мац и др., 2001]) деструкции литосферы. Развитие байкальского 126сегмента зоны контактирования Сибирского и Амурского блоков литосферы (рис. $1, \mathrm{~A})$ на 127раннеорогенном этапе происходило при существенной роли левостороннего сдвига [Балла 128и др., 1990; Delvaux et al., 1997; Семинский, 2009; Мац, 2015], который на 129позднеорогенном этапе сменился растяжением, господствующим в регионе вплоть до 130настоящего времени.

131 Методика исследований включает выделение в рельефе дна и на сейсмических 132разрезах разрывных структур, нарушающих осадочную толщу участка исследований, а 133также их тектонофизический анализ с реконструкцией стресс-тензоров парагенетическим 134методом.

135 Батиметрические данные, полученные в рамках совместных российско136бельгийских исследований (ЛИН CO PAH-RCMG) в 2009 г. [Cuylaerts et al., 2012], 137использованы в работе в виде трехмерной цифровой модели рельефа дна участка 138исследований (рис. 1, Б). Она послужила основой для выделения линеаментов 139спрямленных элементов (уступы, ложбины и пр.), - которые в тектонически активных 140районах в большинстве случаев отражают выход на поверхность разрывных нарушений. 141Преимуществом линеаментного анализа является то, что он позволяет получить 
142информацию о разрывной структуре для всей изучаемой площади, в т.ч. для южной и юго143восточной частей, где нет сейсмических профилей, а рельеф дна наиболее контрастен.

144 Сейсмические разрезы, являющиеся достоверной основой для выделения разрывов, 145были получены в разные годы вследствие реализации сейсмической и сейсмоакустической 146съемки по сети профилей, представленных на рис. 1, Б. Кроме материалов российско147бельгийской экспедиции 2009 г. использовались данные съемок 1992 г. (ИО РАН, ЛИН, US 148Geological Survey), 2002 г. (ЛИН-RСМG) и 2017-2018 гг. (ЛИН, МГУ_Class@Baikal). НСП 149проводилось по стандартной методике [Cuylaerts et al., 2012, Solovyeva et al., 2020].

150 В ходе исследования было обработано 115 разрезов, имеющих глубины от 1700 до 1513000 м. Этот материал позволил получить представление о разломной структуре 152осадочной толщи на участке исследований до уровня $\approx 2000$ м от водной глади озера. При 153этом практически повсеместно интервал в 400 м от поверхности дна может быть 154исследован достаточно детально. Как видно из рис. 1, Б, сейсмические профили имеют 155разную длину и распределяются по площади исследований неравномерно. При отсутствии 156на юге и юго-востоке полноценная сеть разно ориентированных разрезов имеется для 157северной части, тогда как на северо-западе и западе - это субпараллельные профили, 158ориентированные в северо-западном или субмеридиональном направлениях.

159 Анализ сейсмических профилей на предмет выделения разломов в осадочной 160толще проводился визуально, а также при помощи различных программных комплексов, 161которые предоставляют дополнительные способы обработки первичных материалов. Они 162позволяют избавиться от явных «шумов», подчеркнуть несоответствия отдельных частей 163разреза и выделить наиболее крупные из них. Во всех случаях главными признаками для 164выделения разрывной структуры были локализованные смещения однотипного набора 165отражающих горизонтов (пачек) или зоны акустического «хаоса» (рис. 2, Г). Причинами 166появления подобных участков дезинтеграции могут быть наличие в осадках зоны 167трещиноватости или существование канала миграции газонасыщеного флюида (под 168сипами и грязевыми вулканами) (рис. 1, Г), которые в свою очередь, как правило, 169приурочены к конкретным разломным структурам. Для каждого из нарушений 170фиксировались направления падения относительно простирания профиля, угол падения и 171ширина зоны (два последних параметра - по возможности). Кроме того, на схеме участка 172исследований отмечалось место выхода разрыва к поверхности дна или проекция на нее 173окончания дислокации, скрытой в толще осадков.

174 Составленная таким образом схема в совокупности со схемой линеаментов была 175положена в основу итоговой карты разрывной структуры осадочной толщи на изучаемом 176участке Средней котловины оз.Байкал (рис. 2, А). Нарушения, представленные на карте, 177разделены на две группы, отличающиеся по степени достоверности выделения. 178Положение структур без навесных знаков определено только посредством линеаментного 179анализа рельефа. Разрывы с отмеченными углами падения более достоверны, т.к., кроме 180наличия линеамента, его положение либо заверено на одном из сейсмических профилей, 181либо протрассировано через смежные разрезы. При этом направление падения разрыва 182определяется однозначно в отличие от значения угла, для оценки которого проводились 183дополнительные построения. Величина рассматриваемого параметра вычислялась после 184приведения горизонтального и вертикального масштабов в соотношение 1:1 с учетом 185поправки на угол встречи сейсмического разреза и поверхности нарушения. В ходе 186последующей обработки для повышения достоверности результатов исследования 
187основной акцент был сделан на анализе диаграмм разрывов, где определение параметров 188их систем происходит статистическим способом.

189 Так, кроме структурного анализа схемы разрывов (рис. 2, А) и их проявлений на 190разрезах (рис. 2, Г), была проведена тектонофизическая обработка полученных 191материалов, позволяющая восстановить динамические обстановки разрывообразования в 192осадочной толще. Основой для этих реконструкций послужили круговые и розы193диаграммы разрывов, построенные для всей площади исследования или отдельных 194участков в ее пределах. Поскольку положение векторов смещений у разрывов, выделенных 195в толще байкальских осадков, неизвестно, для реконструкций стресс-тензоров применялся 196парагенетический анализ. Его новая модификация в полном объеме представлена в рамках 197метода спецкартирования разломных зон [Семинский, 2014; 2015], в область 198динамического влияния которых в регионах многократной активизации, по определению, 199попадает любой участок земной коры. Метод позволяет путем сравнения природного и 200эталонных парагенезисов разрывов 2-го порядка определить напряженное состояние, 201которое послужило причиной формирования разломной зоны 1-го порядка, а также ее 202морфогенетический тип и элементы внутреннего строения.

203 Каждый эталон, составленный в результате обобщения теоретических, 204экспериментальных и природных закономерностей разрывообразования [Семинский, 2052014; 2015], объединяет полный набор разрывных систем для всех основных типов 206разломных зон и представляется в виде трафарета. Весь набор трафаретов - для правого и 207левого сдвигов, сбросов и взбросов (надвигов) с разными углами падения сместителей 208приведен в цитированных выше публикациях, тогда как рис. 3 иллюстрирует эталонные 209парагенезисы лишь для основных типов разломных зон. Парагенезисы, показанные на рис. 2103, Г в виде трафарета зоны скалывания в плане с указанием простираний систем 211вторичных разрывов, предназначены для использования в том случае, когда углы падения 212тектонических нарушений не известны, и предметом для парагенетического анализа 213является роза-диаграмма их простираний. При наличии полной информации о положении 214разрывов (азимут и угол падения) применяются эталоны разломно-трещинных (рис. 3, A) 215и разломных (рис. 3, Б) парагенезисов, которые составлены в виде круговых трафаретов в 216равноугольной проекции верхней полусферы. На них значками показаны полюсы 217плоскостей магистрального сместителя, вторичных разломов и трещин, взаимное 218положение которых сопоставляется с максимумами полюсов разрывов, выделяющимися 219на круговой диаграмме (стереограмме), построенной для природной разрывной сети в 220соответствии с известными из структурной геологии правилами.

221 В процессе сравнительного анализа эталон, наиболее подходящий для круговой или 222розы-диаграммы по совокупности совпадающих разрывных систем, определяет итоговое 223решение: ориентировку и морфогенетический тип структур 2-го порядка и разломной

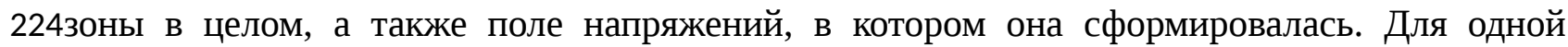
225диаграммы может быть получено одно, два, три и, реже, более решений, 226свидетельствующих о разнотипных подвижках, а, следовательно, и о существовании 227нескольких этапов в развитии изучаемого массива.

\section{Результаты исследований}

230

231 Первоочередным результатом и основой представленных ниже реконструкций 232является схема разрывной структуры центральной части Средней котловины оз. Байкал, 
233представленная на рис. 2, А. В отличие от большинства предыдущих карт [Леви и др., 2341997; Логачев, 2003; Татьков, 2009; Лунина, 2016] она является более детальной, 235поскольку в основу выделения разрывов был положен комплекс современных 236сейсмоакустических материалов и высокоразрешающая ЦМР. Как следствие, крупные 237разломы, выделенные предшественниками в виде непрерывных линий, на рис. 2, А 238представлены серией сегментов, которые зачастую имеют разные углы падения и 239сочленяются друг с другом со смещением через сравнительно короткие поперечные 240разрывы. Таковы описанные выше протяженные продольные разломы, ограничивающие 241крупные участки дна, отличающиеся глубиной. Более того, эти сегментированные 242разломы сопровождаются серией сравнительно мелких разноориентированных разрывов, 243образующих отчетливо выраженные зоны, существование которых подтверждается и при 244анализе структурной картины в разрезе (рис. 2, Г).

245 Установленная закономерность позволила выделить в пределах участка 246исследований полосы сгущения разрывов - разломные зоны, - по которым контактируют 247слабо нарушенные блоки (рис. 2, Б). Среди них, прежде всего, выделяются 248рифтообразующие бортовые зоны Ольхонского (1) и Берегового (2) разломов, а также две 249продольные зоны, ограничивающие наиболее глубокую осевую часть впадины. Одна из 250них (4), согласно [Леви и др., 1997; Татьков, 2009], называется Святоносской, а вторая (3) 251Гидратной [Khlystov 2018; Solovyeva et al., 2020].

252 Следует отметить, что зона разлома Гидратный была детально изучена 253М.А.Соловьевой с коллегами [Solovyeva et al., 2020] на основе большого объема 254материалов НСП и профилографа, часть которых составили сейсмоакустические профили, 255изученные при проведении данного исследования. Наши построения в целом не 256противоречат выводам из цитированной выше работы, согласно которым Гидратный 257разлом, отчетливо выраженный уступом на северо-востоке изучаемой площади (рис. 2, Б), 258сопровождается серией синтетических и антитетических разрывов, нарушающих в 259широкой полосе разные по мощности слои осадочной толщи. Вместе с тем, положение, 260размеры и количество отдельных дислокаций на составленных разными авторами схемах 261заметно отличаются, что обусловлено субъективизмом выделения разрывов на 262сейсмических разрезах и различием использованных при этом дополнительных 263материалов (данные линеаментного, литолого-фациального анализа и др.).

264 Согласно рис. 2, Б, Гидратный разлом (зона 3) располагается в центре 265исследуемого участка и имеет падение на юго-восток под углом 60-80․ Зона разлома по266разному выражена в рельефе дна вдоль ее простирания. Наиболее отчетливо она 267проявлена в северо-восточной части у о. Ольхон, наименее отчетливо - на юго-западе, 268напротив дельты р. Селенги (Кукуйская грива), где, по-видимому, разлом перекрыт 269осадками или затухает. Рассматриваемая зона имеет кулисное строение и состоит из 270четырех сегментов, отчетливо проявленных в рельефе дна. Подобное строение типично 271для структуры сбросовых зон, образующихся в упруго-пластичных моделях над разрывом, 272имитирующем в физическом эксперименте разлом фундамента [Семинский, 2012]. Это 273происходит в результате стадийного развития зоны сброса при формировании ее 274магистрального шва путем объединения близко расположенных отдельных разрывов в 275единый сместитель. На рассматриваемом участке подобное кулисное строение также 276характерно для зоны рифтообразующего Ольхонского разлома, что свидетельствует о 277проявлении общих закономерностей сбросообразования и в этом случае. Кроме кулисного 278строения, они предполагают приближение (а в перспективе - причленение) зоны 
279Гидратного разлома к Ольхонскому на юго-западе, что может быть установлено в 280дальнейшем при развитии исследований за границей рассматриваемого участка.

281 Кроме четырех упомянутых выше крупных разломных зон, имеющих северо282восточное простирание, на изучаемом участке выделяются более мелкие дизъюнктивы 283(рис. 2, Б). Некоторые и них являются сегментами протяженных структур, пересекающих 284Среднюю котловину в поперечном направлении. K ним относятся разломная зона 6, 285северо-западный сегмент которой проходит вдоль пр. Ольхонские ворота, а также зона 5, 286протягивающаяся у северо-восточной границы площади исследования, за которой 287располагается область наибольших глубин изучаемой впадины.

288 Структуры двух описанных систем доминируют на рассматриваемом участке, 289однако в его пределах также проявлены субмеридиональные и субширотные зоны. Роза290диаграмма простираний выделенных на рис. 2, Б разломных структур отражает 291существование, трех главных разломных систем (рис. 2, В). Доминирует система 1, 292простирающаяся на $55^{\circ}$; далее по распространенности следует система 2, 293ориентированная по азимуту $320^{\circ}$; еще меньше на площади исследования распространены 294субмеридиональные зоны (система 3). Субширотные зоны не образуют явно выраженного 295луча, но представлены достаточно крупными дизъюнктивами в приосевом грабене.

296 На рис. 4 показаны результаты парагенетического анализа составленной розы297диаграммы с использованием эталонных трафаретов, представленных на рис. 3, Г. 298Трафареты для зон растяжения, сжатия, правого и левого сдвигов были ориентированы 299вдоль системы 1, которая отражает простирание байкальского сегмента границы между 300Сибирским и Амурским блоками литосферы (рис. 1, А), т.е. той структуры 1-го порядка, в 301пределах которой развивается анализируемая сеть разломных зон. Согласно рис. 4, 302разломная система 2 могла формироваться вместе с системой 1 в обстановке растяжения 303(рис. 4, А) или сжатия (рис. 4, Б) коры в направлении СЗ-ЮВ, а система 3 - при левом 304сдвиге по зоне 1-го порядка с ориентировкой оси сжатия и растяжения, соответственно, в 305меридиональном и широтном направлениях (рис. 4, Г).

306 Следующий шаг парагенетического анализа был предпринят, чтобы подтвердить 307или опровергнуть существование в истории развития региона трех выделенных 308динамических обстановок с использованием независимых данных. Так, для каждой из 309крупных разломных зон (1-8 на рис. 2, Б) восстанавливались поля напряжений на базе 310сопоставления трафаретов рис. 3, А с круговыми диаграммами разрывов, составляющих 311их внутреннюю структуру. При этом для построения диаграмм, кроме нарушений рис. 2, 312А, использовались разрывы, не выходящие на поверхность, но выделяющиеся в пределах 313разломных зон на сейсмических разрезах (см. рис. 1 , Г, рис. 2, Г). Количество нарушений в 314некоторых зонах (например, зона 8) недостаточно для получения однозначных решений. В 315то же время они могут быть учтены в качестве поддержки результатов анализа розы316диаграммы (рис. 2, В), тем более, что в данном случае используется более полная 317информация о положении разрыва - азимут и угол падения.

318 На рис. 5 в качестве примера представлены результаты анализа, проведенного для 319главных представителей разломных зон из трех разных систем. В ходе обработки 320трафареты рис. 3, А сопоставлялись с каждой их исходных диаграмм (рис. 5, А) до тех 321пор, пока максимумы, соответствующие главным системам разрывной сети, не совпали в 322пределах установленных допусков [Семинский, 2014; 2015] с полюсами одного-двух 323эталонных парагенезисов. При этом полюс, соответствующий на трафарете 324магистральному сместителю (Y-сколу), устанавливался на исходной диаграмме так, чтобы 
325это не противоречило элементам залегания анализируемой зоны, установленным по карте 326и разрезам.

327 Для Ольхонской разломной зоны (1) (рис. 2, Б) происхождение всех максимумов 328полюсов разрывов (рис. 5, А) объясняется существованием в регионе двух динамических 3290бстановок, при которых в ее пределах реализовывались левосдвиговые (рис. 5, Б) и 330сбросовые перемещения (рис. 5, В). Так, максимумы № 1, 3, 4, 6, 8 и 9 соответствуют 331первой обстановке, а максимумы № 5, 6 и 7 - второй. Два оставшихся максимума (№ 2 и 33210) в связи с различием разбросов составляющих их полюсов являются сопряженными по 3ззметоду П.Н.Николаева [1992], что позволяет реконструировать стресс-тензор с 334ориентировкой оси растяжения в направлении СВ-ЮЗ. Эта обстановка, как будет показано 335далее, является вторичной в уже установленном для данной зоны поле растяжения в 336направлении С3-ЮВ (рис. 5, В), которая соответствует последнему этапу тектогенеза.

337 Гидратная разломная зона (3) имеет тоже северо-восточное простирание (рис. 2, Б) 338и, судя по результатам анализа, формировалась в тех же динамических обстановках. В 339ходе левосдвигового этапа развития образовались системы разрывов 1, 3, 4, 5 и 7 (рис. 5, 340Б), а при сбросовых перемещениях - системы 2, 4, 7 и 8 (рис. 5, В), причем две из них (4 и 3417) могли быть активны в обеих динамических обстановках.

342 Разломная зона 6, простирающаяся от пр. Ольхонские Ворота в юго-восточном 343направлении до восточного берега оз. Байкал (рис. 2, Б), формировалась при сбросовых и 344правосдвиговых перемещениях, которыми объясняется происхождение практически всех 345(кроме № 5) систем разрывов, проявленных на диаграмме. Судя по их количеству, главным 346было поле растяжения (рис. 5, Б), в котором образовалось шесть систем (1, 3, 4, 7, 8 и 9). 347Сдвигом объясняется происхождение еще трех разрывных направлений - 2, 4 и 6 (рис. 5, 348B).

349 В истории формирования разломной зоны 8 (рис. 2, Б), судя по данным 350парагенетического анализа (рис. 5, Б), был этап левостороннего сдвига, когда образовалось 351то небольшое количество разрывов, которое удалось выявить в ее пределах при анализе 352сейсмических разрезов. Для остальных крупных разломных структур изучаемого участка 353по аналогичной методике были реконструированы следующие этапы подвижек: $30 н а ~ 4-$ 354левый сдвиг и сброс, зона 5 - сброс и правый сдвиг, зона 7 - левый сдвиг.

355 Таким образом, наиболее крупные разломные зоны, образующие на участке 356исследований две главные системы - северо-восточную (система 1 на рис. 2, В) и северо357западную (система 2 на рис. 2, В), согласно результатам парагенетического анализа, 358характеризовались одинаковой историей развития. Внутренняя структура разломных зон 359первой системы (1, 2, 3 и 4 на рис. 2, Б) формировалась в ходе двух этапов, один из 360которых был левосдвиговыми, а другой - сбросовым (рис. 5, Б-В). Для зон второй системы 361(5 и 6 на рис. 2, Б) основными этапами перемещений были сбросовый и правосдвиговый 362(рис. 5, Б-В).

363 Это позволяет уточнить результат парагенетического анализа розы-диаграммы 364простираний разломных зон, выделенных на участке исследований (рис. 4). Так, 365разломная сеть центральной части Средней котловины оз. Байкал формировалась в ходе 366двух этапов тектогенеза:

367 1) при сдвиге с меридиональной ориентировкой оси сжатия и широтной ориентацией 368 оси растяжения (рис. 4, Г), когда северо-восточные зоны были левыми, а северо369 западные - правыми сдвигами; 
2) при растяжении в направлении СЗ-ЮВ (рис. 4, А), когда северо-восточные и северо-западные зоны были сбросами.

372 Третья из предполагаемых ранее динамических обстановок - сжатие в направлении 373СЗ-ЮВ (рис. 4, Б), - должна быть далее исключена из рассмотрения, т.к. внутренняя 374структура ни одной из проанализированных разломных зон не соответствовала взбросу 375или надвигу (рис. 5).

376

377

Обсуждение результатов

378

379 Главным результатом проведенного исследования является вывод о достаточно 380высокой дислоцированности осадочной толщи Средней котловины оз. Байкал. Среди 381разрывов выделяются протяженные структуры, нарушающие осадки на всю глубину 382изученных разрезов (рис. 2), а также более мелкие дислокации, встречающиеся в 383отдельных частях изучаемой толщи. Для первых характерны отчетливые смещения 3840тдельных горизонтов, тогда как вторые проявляются в разрезе участками 385флексурообразного изгиба, т.е., скорее всего, являются зонами повышенной 386трещиноватости без явно выраженного магистрального сместителя. Подобные зоны были 387изучены ранее в керне скважины BDP-98 [Семинский и др., 2001] и состоят из достаточно 388широких (десятки метров) участков развития мелких разрывов, осевая часть которых 389представлена трещинами скола, а периферия - отрывами.

390 Как видно из схем разрывной структуры центральной части Средней котловины оз. 391Байкал (рис. 2, А-Б), протяженные и более мелкие нарушения образуют зоны, сеть 392которых по большому счету является замкнутой. Это позволяет сделать вывод о том, что 39зструктура осадочной толщи оз. Байкал является зонно-блоковой, когда слабо нарушенные 394блоки контактируют по широким зонам с высокой плотностью разрывов [Садовский и др., 3951987; Семинский, 2008]. Судя по схеме рис. 2, Б, внутренняя структура крупных северо396восточных дизъюнктивов находится в осадочной толще на поздних стадиях развития, 397когда сформировался единый магистральный сместитель (например, Ольхонский разлом) 398или его протяженные сегменты (например, Береговой разлом). Однако большинство 399дизъюнктивных структур с позиций тектонофизики [Семинский, 2003; Ben-Zion, 2003] 400являются разломами ранней стадии развития, которые в осадочной толще проявлены в 401виде зон сгущения разрывов 2-го порядка, а магистральный сместитель (разрыв 1-го 402порядка) имеет место в фундаменте, что согласуется с выводами предшественников 403[Moore et al., 1997].

404 Таким образом, проведенное исследование дает представление о внутреннем 405строении центральной части Байкальского рифта. Судя по рис. 2, Б, Г оно во многом 406подобно другим разломным сетям, формирующимся в условиях растяжения земной коры. 407Крупные продольные разломы имеют листрическую форму, падают попарно навстречу 408друг другу, формируя систему вложенных грабенов. Наиболее глубокий приосевой грабен 409ограничен зонами Гидратного (3) и Святоносского (4) разломов. Блоки между ними и 410краевыми дизъюнктивами 1 и 2 в морфологическом отношении представляют ступени 411сравнительно выровненную северо-западную и более крутую юго-восточную.

412 Вторым характерным элементом разломных систем растяжения, выявленным в 413пределах изучаемого участка земной коры, являются поперечные дизъюнктивы [Gibbs, 4141990; Тевелев, 1997; Семинский, 2003]. Их наиболее протяженными представителями 415являются разломы 5 и 6, которые делят зону растяжения на крупные сегменты (рис. 2, Б). 
416Данное семейство разломов ранее выделялось в Байкальском рифте не только на 417сухопутных территориях, где они подчеркиваются долинами впадающих в озеро рек, но и 418на дне озера [Леви и др., 1995; 1997; Levi et al., 1997; Татьков, 2009]. Особенностью этих 419дизъюнктивов является двойственный характер перемещенья крыльев [Семинский, 2003]. 420В разных структурных ситуациях они могут быть сбросами, образующимися в 421продольном по отношению к простиранию рифта поле растяжения 2-го порядка или 422сдвигами, компенсирующими различия скоростей и/или направлений перемещений на 423главных сбросовых сместителях.

424 Остальные направления разломных зон - субмеридиональное и субширотное 425имеют резко подчиненное распространение в пределах изучаемой площади. В то же время 426второе из перечисленных направлений играет заметную роль в зонно-блоковой структуре 427(ЗБС) осадочной толщи, т.к. эта система представлена достаточно протяженными зонами, 428причем почти все они расположены в приосевом грабене (рис. 2, Б). Несмотря на их 429кулисное расположение, предположение о наличии этапа правосдвиговых перемещений по 430осевой зоне для рассматриваемого участка не может быть принято. Во-первых, по 431материалам GPS измерений вектор современных движений коры на площади 432исследований направлен перпендикулярно к простиранию грабена [Лухнев и др., 2013], а 433не под углом, как это характерно для более северо-восточного участка. Во-вторых, 434тектонофизический анализ объемной базы сейсмологических данных [Саньков, 435Добрынина, 2015] позволил установить для рассматриваемой территории растяжение в 436направлении СЗ-ЮВ, а также определить вероятные наклоны плоскостей северо437восточных разрывов в очагах землетрясений - 45-60, - которые соответствуют 438установленным в осадках (рис. 5). В-третьих, по результатам наших реконструкций (рис. 4394) обстановка правого сдвига для формирования сети разрывов на изучаемой площади 440является наименее вероятной. Следовательно, происхождение кулисного ряда 441субширотных зон в осевом грабене на данном этапе исследований следует связывать с 442активизацией системы древних разломов фундамента в кайнозойских динамических 443обстановках.

444 Как было показано в предыдущем разделе статьи, зонно-блоковая структура 445осадочной толщи в пределах центральной части Средней котловины оз. Байкал 446формировалась в двух главных динамических обстановках: I - поле напряжений сдвига с 447меридиональной ориентировкой оси сжатия и широтной ориентацией оси растяжения; II 448поле растяжения в направлении СЗ-ЮВ. Данный вывод не противоречит уже 449цитированным ранее данным предшественников [Балла и др., 1990; Delvaux et al., 1997; 450Семинский, 2009; Мац, 2015], в соответствии с которыми деструкция литосферы на 451раннеорогенном этапе развития Байкальской зоны контактирования Сибирского и 452Амурского блоков литосферы происходила при существенной роли левостороннего 453сдвига, который на рубеже $\approx 3.5$ млн лет сменился растяжением. Эти результаты, 454полученные на основе анализа литологии седиментационной ванны и разрывов главным 455образом в береговых обнажениях, получили здесь структурное подтверждение при 456исследовании сети разломных зон, нарушающих два верхних осадочных комплекса в 457Средней котловине.

458 На рис. 6 для каждого из этапов представлена схема кинематики разломных зон 459изученного участка байкальского дна, предполагаемой для выделенных систем на основе 460эталонных парагенезисов, представленных справа в углу для обстановок левого сдвига 461(рис. 6, А) и растяжения (рис. 6, Б). Достоверность сделанных прогнозов подтверждается 
462кинематическими решениями, полученными при парагенетическом анализе разрывной 463структуры, проведенном для наиболее крупных представителей каждого из направлений 464разломов (зоны 1, 3-8). Разломные зоны представлены на схеме в виде их осей, которые в 465первом приближении могут отражать положение разломов в фундаменте центральной 466части Средней котловины.

467 Как видно из рис. 6, А, на раннеорогенном этапе развития крупной межблоковой 468зоны (1-го порядка), заложившейся у южного выступа Сибирского кратона, в ходе 469левосдвиговых перемещений сформировалась густая сеть разломов, составляющая ее 470внутреннюю структуру. В изученном районе кинематика северо-восточных дизъюнктивов, 471в т.ч. Ольхонского, Берегового, Гидратного и Святтоносского, была аналогична смещениям 472по межблоковой зоне в целом. Подвижки по сопряженному северо-западному 473направлению разломов отвечали правому сдвигу. Субмеридиональные разрывы были 474сбросами, а субширотные - взбросами (или надвигами). Таким образом, на данном, 475левосдвиговом этапе развития межблоковой зоны отдельные участки осадочной толщи 476могли деформироваться в любой из существующих динамических обстановок - при 477сдвиге, растяжении или сжатии, свойственных зонам влияния разломов 2-го порядка. В 478этих условиях выводы о наличии крупных этапов сжатия, обстановок транспрессии (или 479транстенсии) в регионе, как и для рифта в целом, должны базироваться на результатах 480массового (площадного) картирования полей напряжений в байкальских осадках и 481береговых обнажениях, что может быть задачей будущих, более детальных исследований 482этапности деформационного процесса в зоне Байкальского рифта.

483 В соответствии с рис. 6, Б, на позднеорогенном этапе развития разломная структура 484центральной части Средней котловины оз. Байкал развивалась в условиях растяжения. 485Большинство разломных зон, заложившихся в осадочной толще ранее, была 486активизирована: северо-восточные и северо-западные дизъюнктивы в виде сбросов, а 487единичные субширотные - в виде левых сдвигов. Развитие северо-западных сбросов 488происходит в результате продольного растяжения, существование которого в Байкальском 489рифте было установлено на основе анализа геоморфологических и сейсмологических 490материалов [Ламакин, 1968; Golenetsky, Misharina, 1978; Соловьев и др., 1989; 491Мельникова, Радзиминович, 1998; Семинский, 2003].

492 Характер активизации разломов для последних отрезков геологической летописи 493можно оценить, опираясь на данные о проявлениях процессов, сопутствующих 494разрывообразованию, например, сейсмической или флюидной активности. На рис. 6, В 495представлена схема распределения в пределах участка исследований эпицентров 496землетрясений (1994-2020гг; $\mathrm{K} \geq 8.6)$, которые в случае расположения друг от друга не 497далее 1,5 км объединялись общим контуром. Отчетливо видно, что расположение 498сейсмических событий контролируется выявленной на участке исследований разломной 499структурой.

500 В системе северо-восточных разломов наиболее сейсмоактивной является 501Святоносская зона (4), которая на всем протяжении трассируется землетрясениями и 502контролирует два из трех наиболее крупных сгущений эпицентров. Они имеют 503неправильную форму и приурочены к узлам сочленения Святоносского разлома с 504субширотными левосдвиговыми зонами, отходящими от него в сторону приосевого 505грабена. К восточному из этих сгущений относится эпицентр сильнейшего для 506Байкальского рифта Среднебайкальского землетрясения (29.08.1959г; М=6.8), которое 507вызвало разрушения зданий в г. Иркутске (в 185 км от эпицентра), соответствующие 
508интенсивности сотрясений от 5 до 7 баллов в зависимости от типа грунтов [Сетевой 509ресурс: http://seis-bykl.ru].

510 Зона Ольхонского разлома (1) также на всем своем протяжении в пределах участка 511исследований выделяется сгущениями эпицентров и отдельными землетрясениями (рис. 6 , 512В). Их цепочка заметно смещена от оси зоны и еще дальше - от бортового магистрального 513сместителя (рис. 6, Б-В), что при простом пересчете на глубины очагов является 514дополнительным свидетельством существенного наклона его плоскости к юго-востоку 515(60 - по диаграмме на рис. 5, А).

516 Зоны Берегового (2) и Гидратного (3) разломов характеризуются на участке 517исследований слабой сейсмичностью и, как правило, контролируют единичные 518землетрясения с $\mathrm{K} \geq 8.6$. Однако высокая тектоническая активность этих дизъюнктивов не 519вызывает сомнений: зона 2 контролирует сгущения землетрясений северо-восточнее 520участка исследований (рис. 6, В), а к узлу пересечения Гидратного разлома с крупной 521северо-западной зоной 6 приурочена третья по размеру область сгущения эпицентров 522сейсмических событий [Сетевой ресурс: http://seis-bykl.ru].

523 Кроме того, тектоническую активность этих и других разломных зон в настоящее 524время и в недавнем геологическом прошлом доказывает приуроченность к их осям серии 525гидратоносных структур (рис. 6, А). Существование современных скоплений газовых 526гидратов в грязевых вулканах и сипах обусловлено не только наличием в верхних слоях 527донных отложений биогенного (микробиального) метана, но и миграцией его термогенных 528гомологов с глубин в несколько сотен метров и километров по ослабленным зонам 529[Khlystov et al., 2013, Akhamnov et al., 2018]. Кроме того, реализация грязевого вулканизма 530«байкальского типа», имеющего место в обстановке растяжения коры [Khlystov et al., 5312019], не была бы возможна без подвода глубинного тепла посредством подъема 532газонасыщенного раствора по проницаемым разломным зонам.

533

534

\section{Заключение}

535

536 В результате анализа цифровой модели рельефа, построенной по данным 537многолучевого эхолотирования в рамках совместных российско-бельгийских 538исследований в 2009 г. (ЛИН CO PAH-RCMG) и материалов сейсмоакустических 539исследований, полученных в 1992 г. (ИО РАН, ЛИН, US Geological Survey) [Klitgord et al., 5401993] и 2002 г. (ЛИН-RСMG) [Cuylaerts et al., 2012], а также в последние годы (2017-2018 541гг.) - по проекту Class@Baikal [Akhmanov et al., 2019], была составлена схема разрывов, 542нарушающих осадки в центральной части Средней котловины оз. Байкал. Несмотря на 543известные сложности с выделением тектонических нарушений на сейсмических разрезах 544и в рельефе дна озера, высокая разрешающая способность исходных для анализа 545геофизических материалов позволила для многих из них достоверно определить 546положение в плане и разрезе. Это предоставило возможность впервые использовать для 547обработки и интерпретации разрывной структуры байкальских осадков 548тектонофизический подход, основу которого составили реконструкция полей напряжений 549и широкое понимание термина «разлом», который лишь на поздних стадиях развития 550выражен сместителем магистрального типа (разрыв 1-го порядка), а до этого представлет 551широкую зону проявления многочисленных, генетически связанных разрывов 2-го 552порядка. 
1. В результате предпринятого подхода было установлено, что в Средней котловине 55403. Байкал структура осадочной толщи является зонно-блоковой, т.е. представляет 555совокупность слабо нарушенных блоков, контактирующих по достаточно широким зонам 556с относительно высокой плотностью разрывов. ЗБС образована разломными зонами 557северо-восточного и северо-западного простираний при подчиненном распространении 558субмеридиональных и еще более редких субширотных дизъюнктивов. Внутренняя 559структура четырех крупных зон северо-восточной ориентировки, образующих систему из 560двух вложенных грабенов, находится на поздних стадиях развития и, как следствие, 561представлена сместителями магистрального типа - Ольхонским, Береговым, Гидратным и 562Святоносским, - а также оперяющими их разрывами 2-го порядка. Более мелкие зоны 563данного и других направлений представляют ранние стадии развития разломов 564фундамента, которые в чехле осадков проявляются как линейно вытянутые полосы 565сгущения небольших, парагенетически связанных разрывов и трещин. Среди них 566выделяются протяженные поперечные зоны, сегменты которых, подставляя друг друга по 567простиранию, разделяют впадину на сравнительно крупные фрагменты.

568 2. В соответствии с результатами парагенетического анализа разломных зон и 569составляющих их более мелких разрывов установлено, что зонно-блоковая структура 570осадков центральной части Средней котловины оз. Байкал формировалась в двух главных 571полях напряжений. Первое из них соотносится с раннеорогенной, а второе, - с 572позднеорогенной стадиями (этапами) развития Байкальской межблоковой зоны, когда 573осадки деформировались, соответственно, в условиях сдвига и растяжения. Северо574восточные зоны на первом этапе были левыми сдвигами, а на втором сбросами, северо575западные дизъюнктивы - правыми сдвигами, а затем сбросами. Субмеридиональные зоны 576развивались только в ходе первого этапа и были сбросами, а субширотные зоны меняли 577кинематику от взбросовой на 1 этапе до левосдвиговой на 2 этапе.

578 3. Разломная структура дна Средней котловины оз. Байкал, несмотря на специфику 579проявления в слабосцементированных осадках в виде широких зон сгущения мелких 580разрывов, образует единую сеть с дизъюнктивами береговых территорий. Эта сеть на 581современном этапе тектогенеза обеспечивает растяжение земной коры в направлении С3582ЮВ и, как следствие, контролирует проявления процессов, сопутствующих 583разломообразованию, т.е. сейсмическую и газовую активность недр. В пределах 584центральной части Средней котловины большинство землетрясений локализуется в 585разломных зонах северо-восточного простирания, образуя крупные скопления в узлах 586пересечения с северо-западными и субширотными дизъюнктивами. Грязевые вулканы и 587выходы газогидратов приурочены к протяженным нарушениям в осадках, примером 588которых служит разрыв Гидратный, являющийся магистральным сместителем в 589одноименной разломной зоне и вмещающий ряд грязевых вулканов с серией близко 590расположенных сипов.

591

592

\section{Благодарности}

593 Авторы благодарны Центру морских исследований им. Ренарда (RCMG, Бельгия), 594проф. М. Де Батисту и доктору Л. Наудсу за получение сейсмоакустических и 595батиметрических данных в 2002 г. и 2009 г., коллективу проекта Class@Baikal и 596руководителю геофизических работ М.А.Соловьевой за данные 2017-2018 гг. Мы также 597признательны рецензентам к.г.-м.н. П.Г.Дядькову и к.г.-м.н. Ц.А.Тубанову за внимательное 
598прочтение рукописи и конструктивные советы, большинство из которых было учтено в 599окончательном варианте статьи.

600 Работа выполнены в рамках базового бюджетного проекта НИР лаборатории 601тектонофизики ИЗК СО РАН "Современная геодинамика, механизмы деструкции 602литосферы и опасные геологические процессы в Центральной Азии" (№ FWEF-2021-0009) 603и проекта ЛИН СО РАН № 0279-2021-0006.

604

605

\section{Литература}

606

607 Балла 3., Кузьмин М.И., Леви К.Г. Кинематика раскрытия Байкала // Геотектоника. 6081990. - № 2. - С. 80-91.

609 Бурзунова Ю.П. Углы между сопряженными системами приразломных трещин в 610идеализированных и природных парагенезисах, формирующихся в различных 611динамических обстановках // Литосфера. - 2011. - № 2. - С. 94-110.

612 Гольмшток А.Я. Разломообразование и условия стабильности газовых гидратов в 613осадках озера Байкал // Физика Земли. - 2014. - № 4. - C. 70-85. DOI: 61410.7868/S0002333714040036

615 Дучков А.Д., Лысак С.В., Голубев В.А., Дорофеева Р.П., Соколова Л.С. Тепловой 616поток и геотемпературное поле байкальского региона // Геология и геофизика. $-1999 .-\mathrm{T}$. 61740. - № 3. - С. 287-303.

618 Казьмин В.Г., Гольмшток А.Я., Клитгорд К., Мур Т., Хатчинсон Д., Шольц К., Вебер 619И. Строение и развитие района Академического хребта по данным сейсмических и 620подводных исследований (Байкальский рифт) // Геология и геофизика. - 1995. - Т. 35. - № 62110. - С. 164-176.

622 Кузьмин М.И., Лут Б.Ф., Шерстянкин П.П. Обручевский сброс в Байкальской 623впадине как объект исследований наук о Земле // География и природные ресурсы. - 2004. 624- № 2. - С. 35-40.

625 Ламакин В.В. Неотектоника Байкальской впадины. - М.: Наука, 1968. - 247 с.

626 Леви К.Г., Аржанникова А.В., Буддо В.Ю., Кириллов П.Г., Лухнев А.В., 627Мирошниченко А.И., Ружич В.В., Саньков В.А. Современная геодинамика Байкальского 628рифта // Разведка и охрана недр. - 1997. - № 1. - С. 10-20.

629 Леви К.Г., Бабушкин С.М., Бадардинов А.А., Буддо В.Ю., Ларкин Г.В., 630Мирошниченко А.И., Саньков В.А., Ружич В.В., Вонг Х.К., Дельво Д., Колман С. 631Активная тектоника Байкала // Геология и геофизика. - 1995. - Т. 35. - № 10. - С. 154-163.

632 Логачев Н.А. История и геодинамика Байкальского рифта // Геология и геофизика. 6332003. - Т. 44. - № 5. - С. 391-406.

634 Лунина О.В. Цифровая карта разломов для плиоцен-четвертичного этапа развития 635земной коры юга Восточной Сибири и сопредельной территории Северной Монголии // 636Геодинамика и тектонофизика. - 2016. - T. 7. - N. 3. - C. 407-434. DOI: 637https://doi.org/10.5800/GT-2016-7-3-0215

638 Лухнев А.В., Саньков В.А., Мирошниченко А.И., Ашурков С.В., Бызов Л.М., 639Саньков А.В., Башкуев Ю.Б., Дембелов М.Г., Кале Э. Современные деформации земной 640коры в области сочленения сегментов рифтов центральной части Байкальской рифтовой 641системы по данным GPS геодезии // Геология и геофизика. - 2013. - Т. 54. - № 11. - С. 6421814-1825.

643 Мац В.Д. Байкальский рифт: плиоцен (миоцен) - четвертичный эпизод или продукт 644длительного развития с позднего мела под воздействием различных тектонических 645факторов. Обзор представлений // Геодинамика и тектонофизика. - 2015. - Т. 6. - № 4. - С. 646467-489. DOI: https://doi.org/10.5800/GT-2015-6-4-0190

647 Мац В.Д. Возраст и геодинамическая природа осадочного выполнения 648Байкальского рифта // Геология и геофизика. - 2012. - Т. 53. - № 9. - С. 1219-1244. 

650Шимараев М.Н., Хлыстов О.М. Кайнозой Байкальской рифтовой впадины: строение и 651геологическая история // Новосибирск: Изд-во СО РАН, филиал «Гео», 2001. - 252 с.

652 Мельникова В.И., Радзиминович Н.А. Механизм очагов землетрясений 653Байкальского региона за 1991-1996 гг. // Геология и геофизика. - 1998. - Т. 39. - № 11. - С. 6541598-1607.

655 Николаев П.Н. Методика тектонодинамического анализа / Под ред. Н.И.Николаева. 656- М.: Недра, 1992. - 295 с.

657 Садовский М.А., Нерсесов И.Л., Писаренко В.Ф. Иерархическая дискретная 658структура литосферы и сейсмический процесс // Современная тектоническая активность 6593емли и сейсмичность. - М.: Наука, 1987. - С. 182-191.

660 Саньков В.А., Добрынина А.А. Современное разломообразование в земной коре 661Байкальской рифтовой системы по данным о механизмах очагов землетрясений // Докл. 662PAH. - 2015. - T. 465. - № 3. - C.347-352. DOI: 10.7868/S0869565215330233

663 Семинский К.Ж. Внутренняя структура континентальных разломных зон. 664Тектонофизический аспект. - Новосибирск: Изд-во СО РАН, Филиал «Гео», 2003. - 244 с.

665 Семинский К.Ж. Внутренняя структура разломных 3он: пространственно666временная эволюция на основе результатов физического моделирования // Геодинамика и 667тектонофизика. - 2012. -T 3, № 3. - C. 183-194. DOI: https://doi.org/10.5800/GT-2012-3-36680070

669 Семинский К.Ж. Главные факторы развития впадин и разломов Байкальской 670рифтовой зоны: тектонофизический анализ // Геотектоника. - 2009. - № 6. - С. 1-17.

671 Семинский К.Ж. Иерархия зонно-блоковой струкутры Центральной и Восточной 672Азии // Геология и геофизика. - 2008. - Т. 49. - № 10. - С. 771-779.

673 Семинский К.Ж. Спецкартирование разломных зон земной коры. Статья 1: 674теоретические основы и принципы // Геодинамика и тектонофизика. - 2014. - Т. 5. - № 2. 675C. 445-467. DOI: https://doi.org/10.5800/GT-2014-5-2-0136

676 Семинский К.Ж. Спецкартирование разломных зон земной коры. Статья 2: 677Основные этапы и перспективы // Геодинамика и тектонофизика. - 2015. - Т. 6. - № 1. - С. 6781-43. DOI: https://doi.org/10.5800/GT-2015-6-1-0170

679 Семинский К.Ж., Карабанов Е.Б., Кузьмин М.И. Тектонические нарушения осадков 680озера Байкал (по материалам исследования бурового керна BDP-98) // Геология и 681геофизика. - 2001. - Т. 42, - № 1-2. - С. 308-318.

682 Семинский К.Ж., Кожевников Н.О., Черемных А.В., Поспеева Е.В., Бобров А.А., 683Оленченко В.В., Тугарина М.А., Потапов В.В., Зарипов Р.М., Черемных А.С. 684Межблоковые зоны в земной коре юга Восточной Сибири: тектонофизическая 685интерпретация геолого-геофизических данных // Геодинамика и тектонофизика. - 2013. 686T. 4. - № 3. - C. 203-278. DOI: https://doi.org/10.5800/GT-2013-4-3-0099

687 Семинский К.Ж., Черемных А.В. Трещинные сети и напряженное состояние 688кайнозойских осадков байкальского рифта: новые возможности структурно689парагенетического анализа // Геология и геофизика. - 2011. - Т. 52, № 3. - С. 450-469.

690 Сетевой ресурс: http://seis-bykl.ru

691 Соловьев С.Л., Ковочев С.А., Мишарина Л.А. и др. Сейсмичность поперечных 692нарушений в Ольхон-Святоносской зоне оз. Байкал // Докл. АН СССР. - 1989. - Т. 309. -№ 6931. - С. 61-64.

694 Татьков Г.И. Геофизический мониторинг напряженно-деформированного состояния 695природных и технических систем: Автореф. дис. ... докт. геол.-мин. наук. -Иркутск, 2009. $696-43$ c.

697 Тевелев А.В. Кинематика трансферов // Структурные парагенезы и их ансамбли. 698М.: ГЕОС, 1997. - С. 172-174.

699 Хатчинсон Д., Гольмшток А.Я., Зоненшайн Л.П., Мур Т.К., Шольц К.А., Клитгорд 700К.Д. Особенности строения осадочных толщ оз. Байкал по результатам многоканальной 
701сейсмической съемки (1989 г.) // Геология и геофизика. - 1993. - Т. 34. - № 10-11. - С. 2570236.

703 Хлыстов O.M., Кононов Е.Е., Хабуев А.В., Белоусов О.В., Наудс Л. Геолого704геоморфологические особенности Посольской банки и Кукуйской гривы озера Байкал // 705Геология и геофизика. - 2016. - Т. 57. - № 12. - С. 2229-2239. DOI: 10.15372/GiG20161208 706 Хлыстов О.М., Минами Х., Хачикубо А., Ямашита С., Де Батист М., Наудс Л., 707Хабуев А.В., Ченский А.Г., Губин Н.А., Воробьева С.С. Возраст грязевой брекчии 708грязевых вулканов Академического хребта озера Байкал // Геодинамика и тектонофизика. 7092017. - T. 8. - № 4. - C. 923-932. DOI: https://doi.org/10.5800/GT-2017-8-4-0324

710 Шерман С.И., Днепровский Ю.И. Поля тектонических напряжений Байкальской 711рифтовой зоны // Геотектоника. - 1989. - № 2. - С. 101-112.

712 Akhmanova G.G., Khlystov O.M., Solovyeva M.A., Efremov V.N., Vidishcheva O.N., 713Mazzini A., Kudaev A.A., Bulanova I.A., Barymova A.A.,. Gordeev E.K, Delengov M.T., 714Egoshina E.D., Sorokoumova Ya.V., Ponimaskin P.O. Newly Discovered Hydrate-Bearing 715Structure in Lake Baikal // Moscow University Geology Bulletin. - 2018. - V. 73. - N 6. - P. 716582-587.

717 Akhmanov G.G. and Class@Baikal Team. The newly discovered «MSU» gas-hydrate 718bearing seep and other findings: five years of the Class@Baikal Project // Труды VII 719Международной научно-практической конференции “Морские исследования и 720образование (MARESEDU-2018)” T. II (IV). - Тверь: ООО «ПолиПРЕСС», 2019. - С. 5172155.

722 Ben-Zion Y., Sammis C.G. Characterization of fault zones // Pure and Applied 723Geophysics. - 2003. - V. 160. - N 3-4. - P. 677-715. DOI: 10.1007/978-3-0348-8010-7_11

724 Ceramicola S., Rebesko M., De Batist M., Khlystov O. Seismic evidence of small-scale 725lacustrine drifts in Lake Baikal (Russia) // Marine Geophysical Researches. - 2001. - V. 22. - P. 726445-461. DOI: 10.1023/A:1016351700435

727 Cuylaerts M., Naudts L., Casier R., Khabuev A.V., Belousov O.V., Kononov E.E., 728Khlystov O., De Batist M. Distributionand morphology of mud volcanoes and other fluid flow729related lake-bed structures in Lake Baikal, Russia // Geo-Mar. Lett. - 2012. - V. 32. - P. 437730451. DOI: 10.1007/s00367-012-0291-1

731 De Batist M., Klerkx J., Van Rensbergen P., Vanneste M., Poort J., Golmshtok A.Y., 732Kremlev A.A., Khlystov O.M., Krinitsky P. Active hydrate destabilization in Lake Baikal, 733Siberia? // Terra Nova. - 2002. - V. 14. - P. 436-442. DOI: 10.1046/j.1365-3121.2002.00449.x

734 Delvaux D., Moyes R., Stapel G., Petit C., Levi K., Miroshnitchenko A., Ruzhich V., 735San'kov V. Paleostress reconstruction and geodynamics of the Baikal region, Central Asia. Pt. II: 736Cenozoic rifting // Tectonophysics. - 1997. - V. 282. - P. 1-38. DOI: 10.1016/S00407371951(97)00210-2

738 Gibbs A.D. Linked fault families in basin formation // J. of Struct. Geol. - 1990. - V. 12. 739- N 5/6. - P. 795-803. DOI: 10.1016/0191-8141(90)90090-L

740 Golenetsky S.I., Misharina L.A. Seismicity and earthquake focal mechanisms in the 741Baikal rift zone // Tectonophysics. - 1978. - V. 45. - P. 71-85.

742 Khlystov O.M., Khabuev A.V., Minami H., Hachikubo A., Krylov A.A. Gas hydrates in 743Lake Baikal // Limnology and Freshwater Biology. - 2018. - V.1. - P. 66-70. 744DOI: 10.31951/2658-3518-2018-A-1-66

745 Khlystov O.M., Poort J., Mazzini A., Akhmanov G.G., Minami H., Hachikubo A., 746Khabuev A.V., Kazakov A.V., De Batist M., Naudts L., Chensky A.G., Vorobeva S.S. Shallow747rooted mud volcanism in Lake Baikal // Marine and Petroleum Geology. - 2019. - N 102. - P. 748580-589. DOI: 10.1016/j.marpetgeo.2019.01.005

749 Khlystov O.M., De Batist M., Minami H., Hachikubo A., Khabuev A.V., Kazakov A.V. $750 \mathrm{Gas}$ hydrates and their position in the sedimentary strata and in the geological structure of Lake 751Baikal. In J.Mienert (ed.). World atlas of submarine gas hydrates in continental margins. 752Springer. 2021. (in press) 
753 Khlystov O.M., De Batist M., Shoji H., Hachikubo A., Nishio S., Naudts L., Poort J., 754Khabuev A., Belousov O., Manakov A., Kalmychkov G. Gas hydrate of Lake Baikal: discovery 755and varieties // J. Asian Earth Sciences. - 2013. - V. 62 (1). - P. 162-166. 756DOI: 10.1016/j.jseaes.2012.03.009

757 Klerkx J., De Batist M., Poort J., Hus R., Van Rensbergen P., Khlystov O., Granin N. 758Tectonically controlled methane escape in Lake Baikal // Lombardi S., Altunina L.K., Beaubien 759S.E. (Eds.). Advances in the geological storage of carbon dioxide. - Springer, Netherlands (Part 760III), 2006. - P. 203-219. DOI: 10.1007/1-4020-4471-2_17

761 Klitgord, K.D., Golmshtok, A.Y., Scholz, C.A., Akentiev, L., Nichols, D., Schneider, C., 762McGill, J., Foster, D., Unger, D., 1993. Seismic survey of Lake Baikal, Siberia. - Cruise Report 763R.V. Balkhash. US Geological Survey Open-File Report OF-93-201 - 25 pp.

764 Levi K.G., Miroshnichenko A.I., San'kov V.A. et al. Active Faults of the Baikal 765Depression. Failles actives de la depression du Baikal // Bulletin Centre Research Elf 766Exploration Production. - 1997. -V. 21(2). - P. 399-434.

767 Mats V.D., Khlystov O.M., De Batist M., Ceramicola S., Lomonosova T.K., Klimansky 768A. Evolution of the Academician Ridge accommodation zone in the central part of the Baikal 769rift, from high-resolution reflection seismic profiling and geological field investigations // Int. J. 770Earth Sci. - 2000. - V. 89. - P. 229-250. DOI: 10.1007/s005310000094

771 Moore T.C., Klitgord K.D., Golmstok A.Ya., Weber E. Sedimentation and subsidence 772patterns in the central and north basins of Lake Baikal from seismic stratigraphy // Geol. Soc. 773Amer. Bull. - 1997. - V. 109. - P. 746-766. DOI: 10.1130/00167747606(1997)109<0746:SASPIT>2.3.CO;2

775 Petit C., Deverchere J. Structure and evolution of the Baikal rift: A synthesis // Geochem. 776Geophys. Geosyst. - 2006. - V. 7. - P. 1-26. DOI: 10.1029/2006GC001265

777 Scholz C.A., Hutchinson D.R. Stratigraphic and structural evolution of the Selenga Delta 778accommodation zone, Lake Baikal rift, Siberia // Int. J. Sci. - 2000. - V. 89. - P. 212-228. 779DOI: $10.1007 / \mathrm{s} 005310000095$

$780 \quad$ Scholz C.A., Moore T.C., Hutchinson D.R., Golmshtok A.Ja., Klitgord K.D., Kurotchkin 781A.G. Comparative sequence stratigraphy of low-latitude versus high-latitude lacustrine rift 782basins: seismic data examples from the East African and Baikal rifts // Palaeogeography, 783Palaeoclimatology, Palaeoecology. - 1998. - V. 140. - P. 401-420. DOI: 10.1016/S00317840182(98)00022-4

785 Solovyeva M.A., Akhmanov G.G., Mazzini A., Khabuev A.V., Khlystov O.M. The 786Gydratny Fault zone of Lake Baikal // Limnology and Freshwater Biology. - 2020. - V. 1. - P. 787368-373. DOI: 10.31951/2658-3518-2020-A-1-368

788 Van Rensbergen P., De Batist M., Klerkx J., Hus R., Poort J., Vanneste M., Granin N., 789Khlystov O., Krinitsky P.. Sublacustrine mudvolcanoes and methane seeps caused by 790dissociation of gas hydrates in Lake Baikal // Geology. - 2002. - V. 30. - P. 631-634. 791DOI: 10.1130/0091-7613(2002)030<0631:SMVAMS>2.0.CO;2 
Рис. 1. Материалы, использованные для выявления разрывной структуры участка исследований, и его положение на схеме разломов Байкальской рифтовой зоны (БРЗ).

А. Схема позднекайнозойских разломов БРЗ и прилегающей территории: 1-2 - генеральные (L > 80 км) (а) и региональные (34 < L < 80 км) (б) разломы, отчетливо (1) и менее отчетливо (2) проявленные в рельефе (I - Береговой, II - Приморский, III - Ольхонский); 3 - крупные озера; 4 - главные кайнозойские впадины (в т.ч. 1 - Чарская, 2 - Нижне-Муйская, 3 - Верхне-Муйская, 4 - Верхнеангарская, 5 - Кичерская, 6 - Баунтовская, 7 - Ципиканская, 8 - Баргузинская, 9 - Байкальская, 10 - Удинская, 11 - Тункинская, 12 Хубсугульская, 13 - Китойская, 14 - Голуметская, 15 - Окинская, 16 - Ийская); 5 - крупные базальтовые поля; 6 - гидросеть; 7 - контур участка исследований.

Б. Положение сейсмических профилей на трехмерной модели рельефа дна озера: жирные сплошные линии - профили с зафиксированными на разрезах смещениями; тонкие пунктирные линии - профили без зафиксированных смещений (слева - шкала глубин). I-I' и II-II' - разрезы, описанные в тексте.

В. Трехмерная модель рельефа в районе профиля I-I'.

Г. Сейсмический разрез осадочной толщи вдоль профиля I-I', на котором черными линиями показаны разрывы, а синей стрелкой - миграция флюида к поверхности дна в зоне дезинтеграции грязевого вулкана «Новосибирск».

\section{Рис. 2. Разломная структура изученного участка Средней котловины оз. Байкал.}

А. Схема разрывов осадочной толщи, представленная на трехмерной модели дна озера со шкалой глубин: 1-2 - разрывы, для которых определен (2) и не определен (1) угол падения поверхности сместителя.

Б. Схема зонно-блоковой структуры осадочной толщи: 1 - разрывы; 2 - разломные зоны (а) и блоки (б); 3 - номера зон (в т.ч. 1 - Ольхонская, 2 - Береговая, 3 - Гидратная, 4 - Святоносская); 4 - оси крупных (а), средних (б) и мелких (в) разломных зон; 5 - положение сейсмического профиля II-II'.

В. Роза-диаграмма простираний осей разломных зон, представленных на рис. 2, Б (номера - главные разломные системы).

Г. Сейсмический разрез по линии II-II'. Черными пунктирными линиями показано предполагаемое положение разрывов в осадочной толще, серым пунктиром - оси разломных зон (цифра в кружке - номер), а навесными знаками - их кинематика на последнем этапе тектогенеза: стрелка - висячее крыло перемещается по падению, кружок с точкой - крыло перемещается на зрителя, кружок с крестиком - крыло перемещается от зрителя. Н - примерное расстояние от поверхности воды.

Рис. 3. Базовые парагенезисы разрывов, имеющих место в зонах взброса, сброса, левого и правого сдвигов.

Парагенезисы представлены на круговых диаграммах (верхняя полусфера, сетка Вульфа) в полюсах (А-Б) и плоскостях (B), а также простираниями плоскостей в плане (Г). Полюсы вертикальных разрывных систем показаны половинками значков на противоположных сторонах круга. Латинскими буквами обозначены системы, однотипные в механическом отношении (Г).

1-5 - полюсы (а), плоскости (б) и простирания плоскостей (в) сместителей 1-го (значок крупнее) и 2-го (значок мельче) порядка, являющихся взбросами (1), сбросами (2), левыми (3) и правыми (4) сдвигами, а также трансформационными разрывами (5); 6 - положение полюса второстепенной или дополнительной системы тройственного парагенезиса разрывов (цвет знака соответствует цвету главной системы парагенезиса); 7-9 - зоны взброса (7), сброса (8), левого и правого сдвигов (9); 10-11 - оси напряжений сжатия (10) и растяжения (11), занимающих субгоризонтальное (а) или субвертикальное (б) положение.

Рис. 4. Реконструкция динамических обстановок формирования сети разломных зон в пределах участка исследований, проведенная с использованием эталонных парагенезисов разрывов 2-го порядка, формирующихся в зоне растяжения (А), сжатия (Б), правого (В) или левого (Г) сдвигов. Контур розы-диаграммы, представленной на рис. 2, В, показан серым цветом; номерами в кружках обозначены разломные системы. 
1 - плоскости левых сдвигов (а), правых сдвигов (б), сбросов (в) и взбросов (надвигов) (г) 2-го порядка (латинские буквы - системы, однотипные в механическом отношении); 2 - плоскости трансформационных сдвигов 2-го порядка (в зоне сдвига совпадают с плоскостью рисунка); 3-5 - зоны левого сдвига (3), сброса (4) и взброса (надвига) (5) 1-го порядка; 6 - оси напряжений сжатия (а) и растяжения (б), занимающих субгоризонтальное (стрелка) или субвертикальное (точка) положение в пространстве.

Рис. 5. Результаты парагенетического анализа сетей разрывов, составляющих структуру четырех крупных разломных зон (1, 3, 6 и 8) участка исследований.

А. Круговые диаграммы разрывов, построенные на сетке Вульфа (верхняя полусфера) для каждой из анализируемых разломных зон.

Б-В. Решения о динамических обстановках в которых происходило формирование разрывной структуры анализируемых разломных зон. Под каждым рисунком обозначен вид трафарета (согласно рис. 3 и [Бурзунова, 2011]) и элементы залегания максимума, который при совмещении диаграммы и трафарета считался соответствующим магистральному сместителю разломной зоны.

1 - номер максимума; 2-9 - полюса разрывных систем, составляющих эталонные трафареты: 2 - полюс левосдвигового сместителя 1-го (а) или 2-го (б) порядка; 3 - полюс правосдвигового сместителя 1-го (а) или 2-го (б) порядка; 4 - полюс взбросового (надвигового) сместителя 1-го (а) или 2-го (б) порядка; 5 - полюс сбросового сместителя 1-го (а) или 2-го (б) порядка; 6 - полюс сбросо-сдвигового сместителя 2-го порядка (полюса одного тройственного парагенезиса разрывных систем показаны одинаковым цветом); 7 - полюс взбросо(надвиго)-сдвигового сместителя 2-го порядка (полюса одного тройственного парагенезиса разрывных систем показаны одинаковым цветом); 8 - полюс трансформационного сместителя 2-го порядка; 9 - полюс второстепенной или дополнительной системы тройственного парагенезиса разрывов. На эталонном трафарете все три полюса каждого тройственного парагенезиса разрывов показаны одним цветом, что в ряде случаев отражается наложением 2-4 разноцветных и разнотипных значков.

Рис. 6. Схемы разрывной структуры участка исследований (оз. Байкал, Средняя котловина), активной на различных этапах тектогенеза.

А. Схема кинематики разломных зон, предполагаемой для каждой из их систем на основе эталонного парагенезиса разрывов 2-го порядка (см. вверху справа), соответствующего обстановке левого сдвига: 1 - роза-диаграмма простираний осей разломных зон; 2 - оси крупных (а), средних (б) и мелких (в) разломных зон; 3-6 - оси активных разломных зон сбросового (3), левосдвигового (4), правосдвигового (5), взбросового (надвигового) (6) типа; 7 - номера осей разломных зон; 8 - гидратоносные структуры (согласно [Khlystov et al., 2018; 2021] с дополнениями).

Б. Схема кинематики разломных зон, предполагаемой для каждой из их систем на основе эталонного парагенезиса разрывов 2-го порядка (см. вверху справа), соответствующего обстановке растяжения: 1 - розадиаграмма простираний осей разломных зон; 2 - оси крупных (а), средних (б) и мелких (в) разломных зон; 3-5 - оси активных разломных зон сбросового (3), правосдвигового (4), левосдвигового (5) типа; 6 - оси разломных зон, не активных на этапе растяжения; 7 - номера осей разломных зон.

В. Схема разрывной структуры участка исследований, на которой показано положение эпицентров землетрясений с K $\geq 8.6$, произошедших в период 1994-2020 гг. (http://seis-bykl.ru): 1-2 - разрывы, для которых определен (2) и не определен (1) угол падения поверхности сместителя; 3 - эпицентры землетрясений (а) и их сгущения (б); 4 - эпицентр Среднебайкальского землетрясения (29.08.1959г.; M=6.8). 

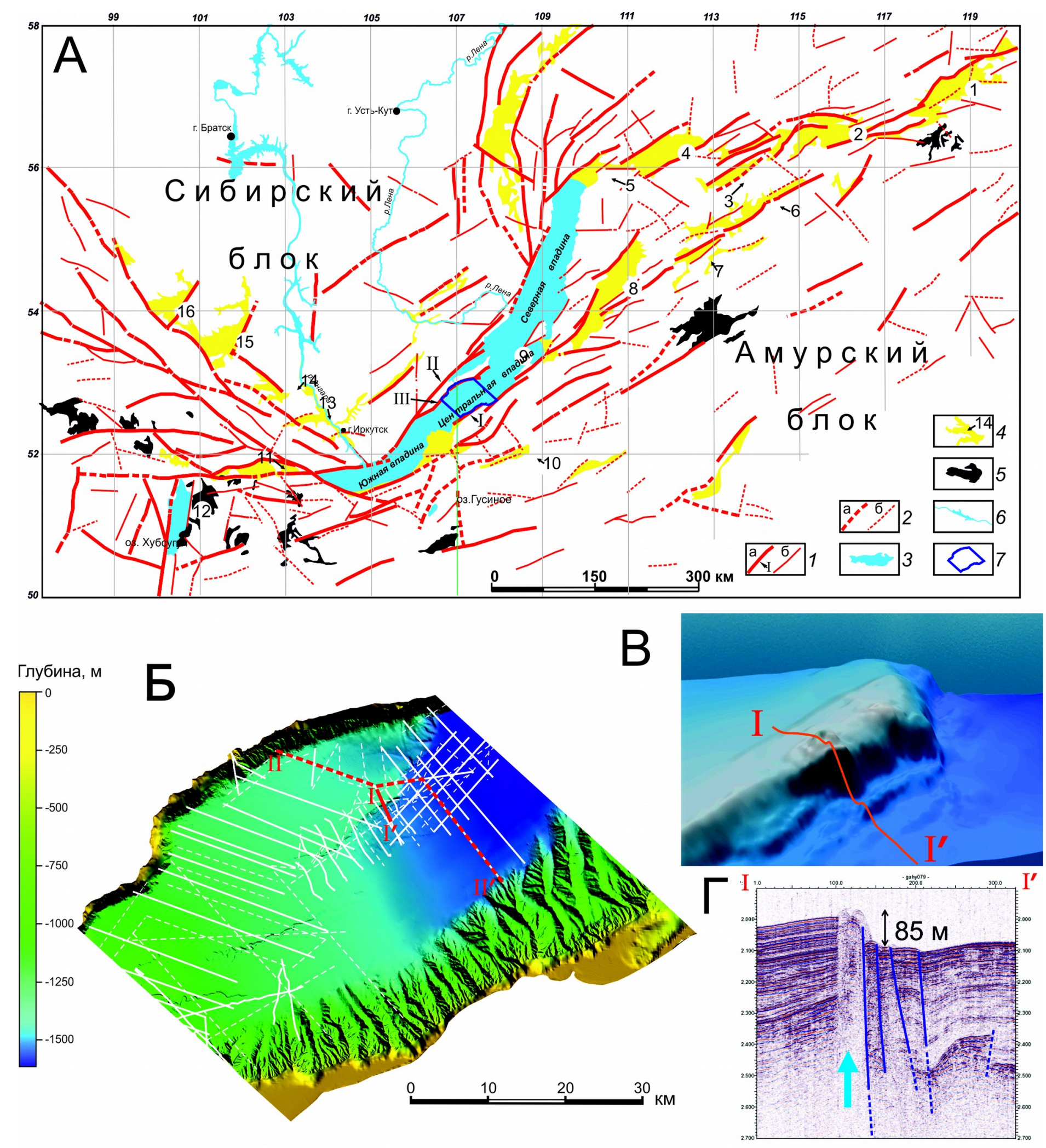


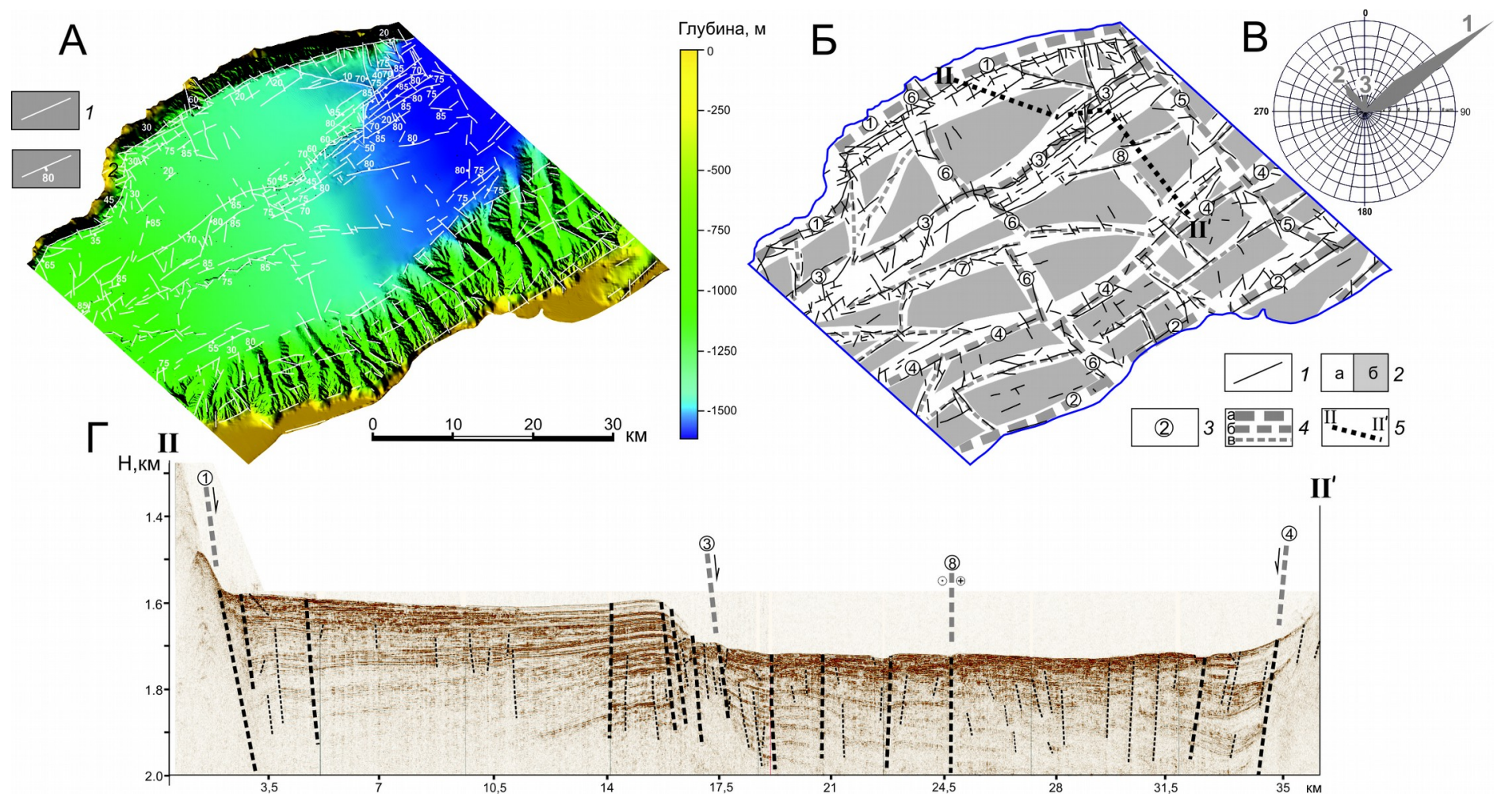




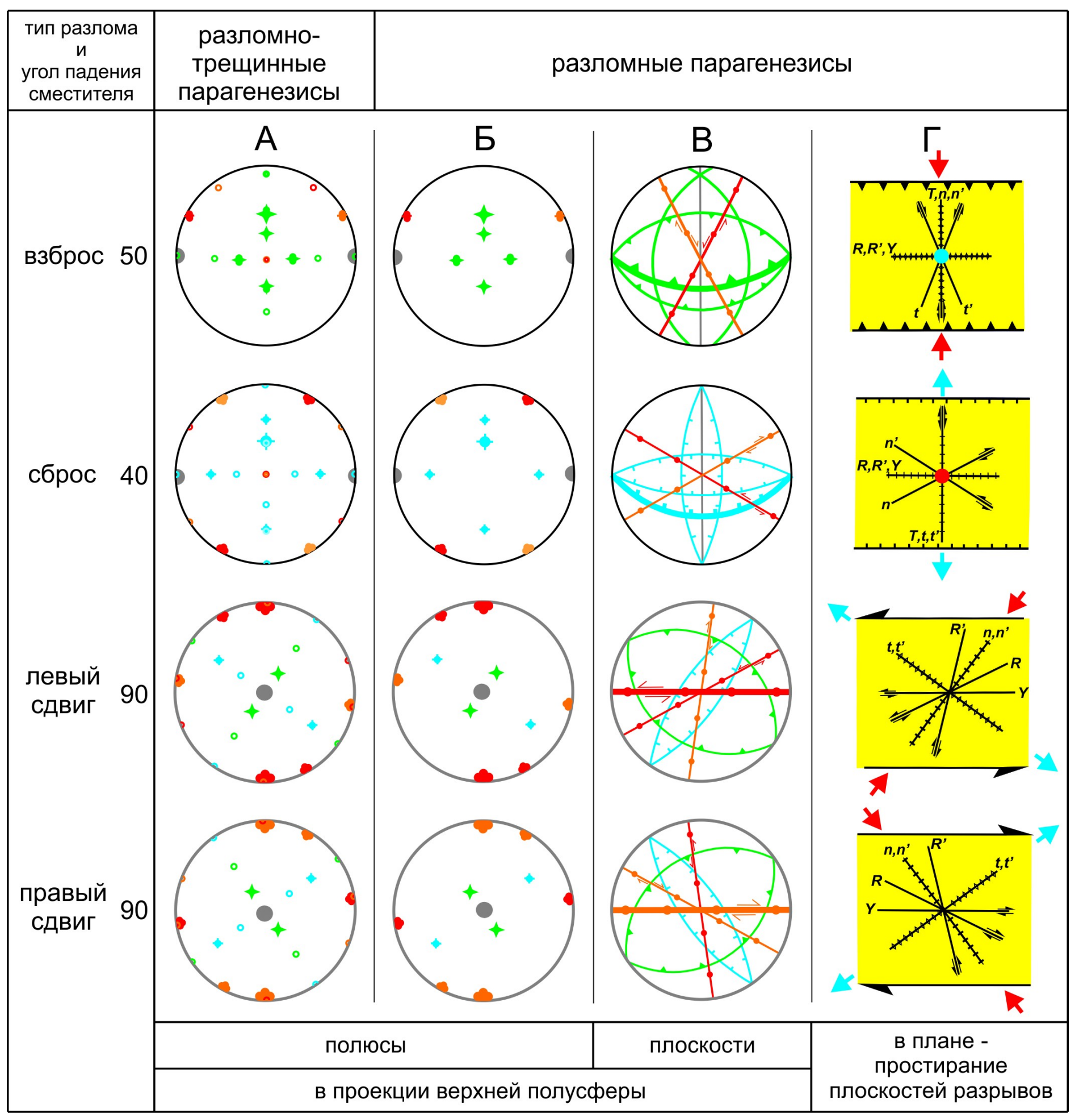

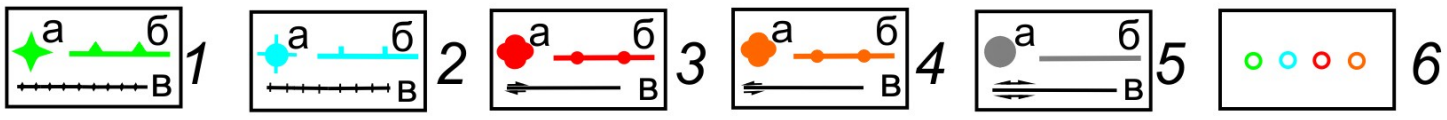

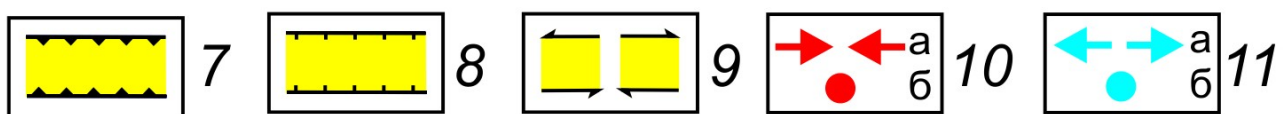



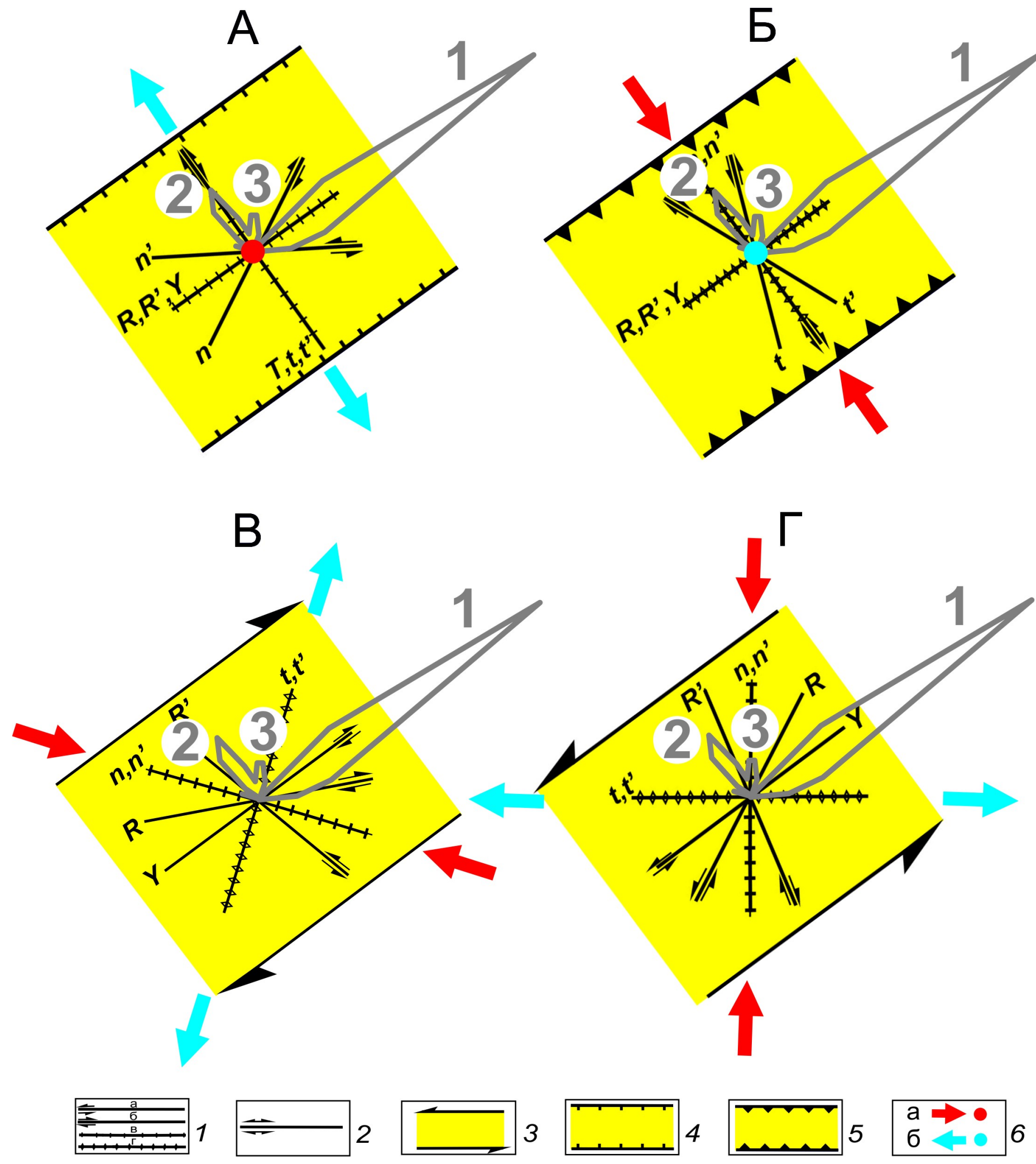

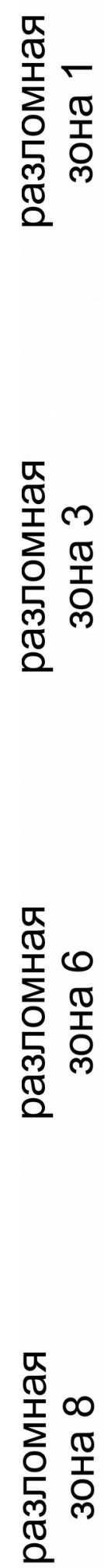

A

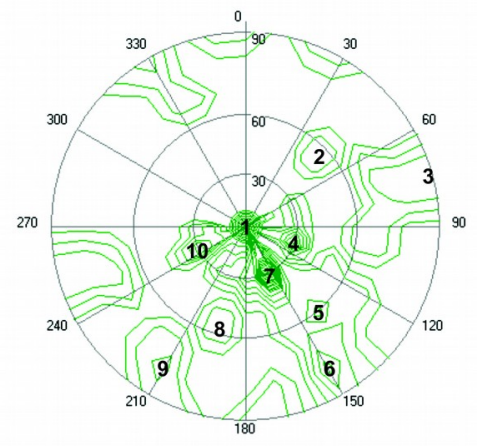

количество разрывов: 58 шт. величина окна осреднения: $10^{\circ}$

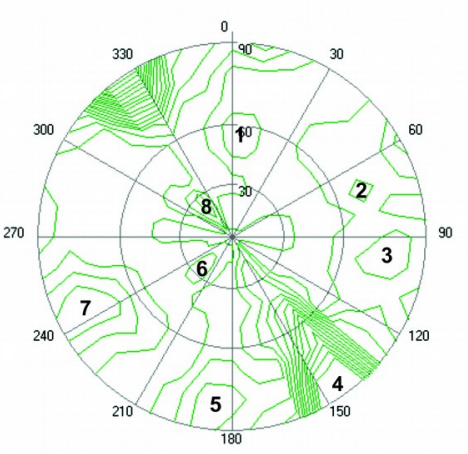

количество разрывов: 173 шт величина окна осреднения: $10^{\circ}$

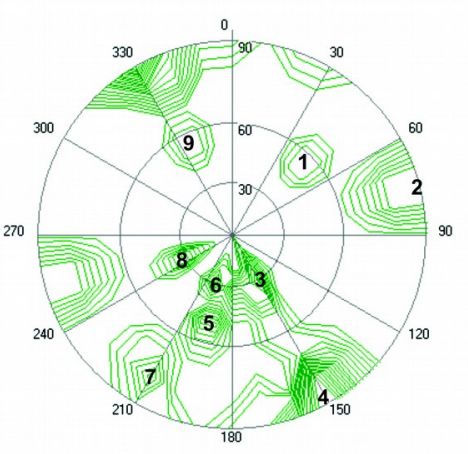

количество разрывов: 30 шт. величина окна осреднения: $10^{\circ}$

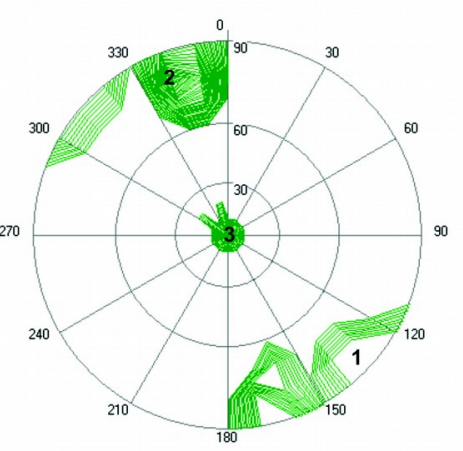

количество разрывов: 11 шт. величина окна осреднения: $10^{\circ}$
B

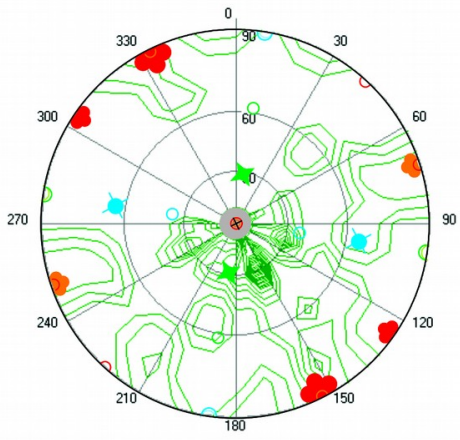

трафарет: левый сдвиг сместитель: $150^{\circ} \angle 80^{\circ}$

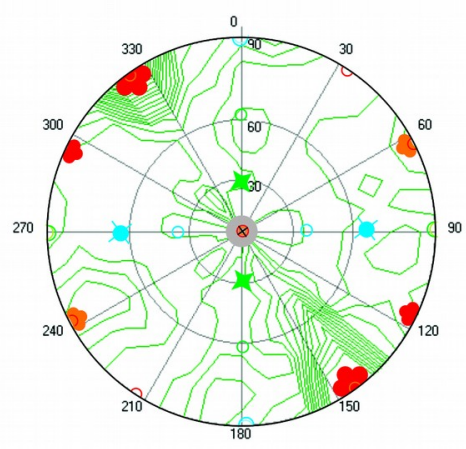

трафрарет: левый сдвиг сместитель: $140^{\circ} \angle 85^{\circ}$

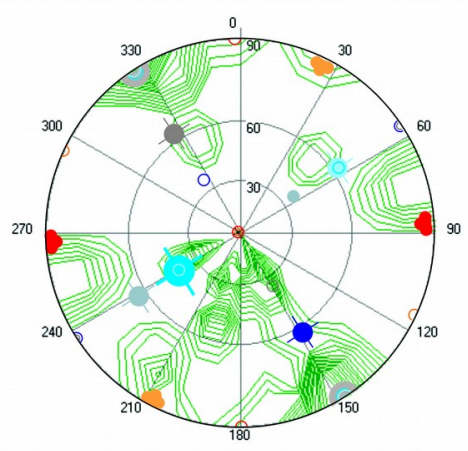

трафрарет: сброс-40 сместитель: $250^{\circ} \angle 30^{\circ}$

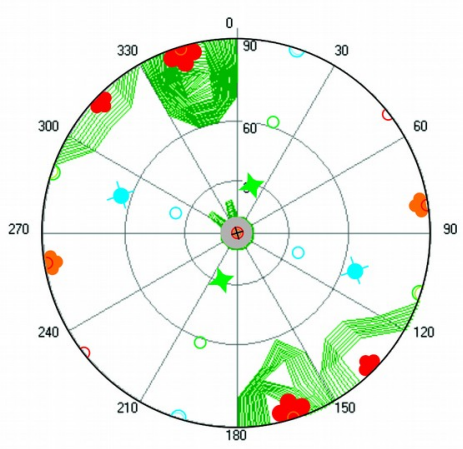

трафарет: левый сдвиг сместитель: $340^{\circ} \angle 80^{\circ}$
B

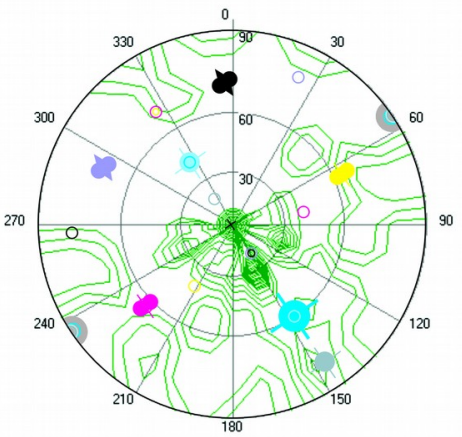

трафрарет: сброс-60 сместитель: $55^{\circ} \angle 80^{\circ}$

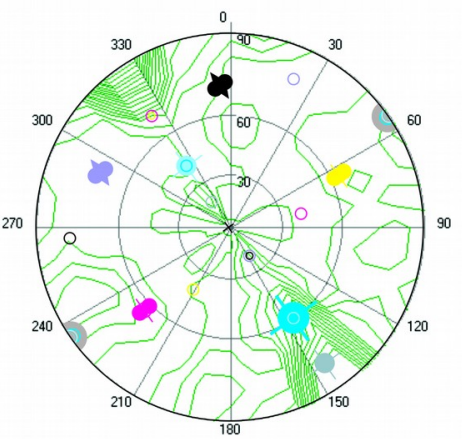

трафарет: сброс-60 сместитель: $140^{\circ} \angle 60^{\circ}$

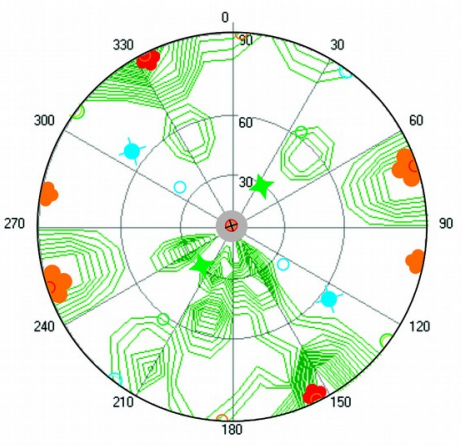

трафрарет: правый сдвиг сместитель: $255^{\circ} \angle 90^{\circ}$
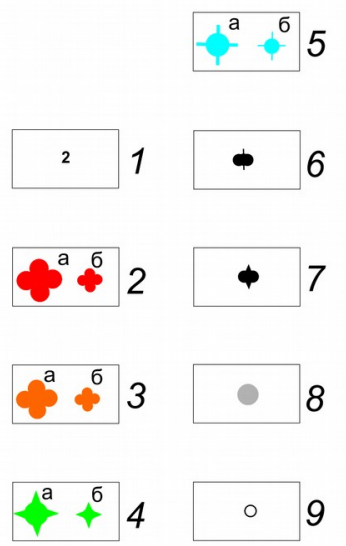

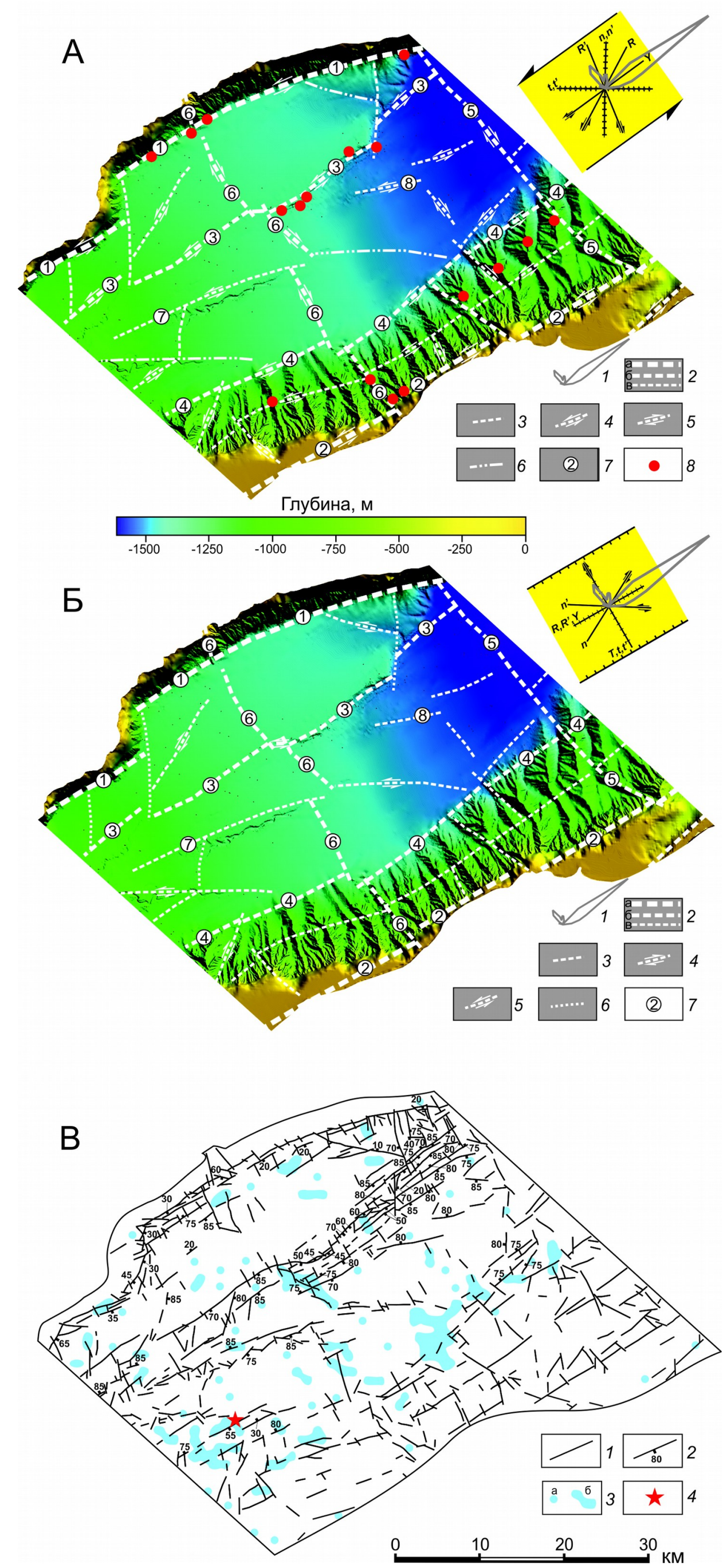